\title{
Phytochemical Composition and Enzyme Inhibition Studies of Buxus papillosa C.K. Schneid
}

\author{
Hammad Saleem ${ }^{1,2, *}$, Thet Thet Htar ${ }^{1}$, Rakesh Naidu ${ }^{3} \mathbb{D}$, Gokhan Zengin ${ }^{4}(\mathbb{D}$, \\ Marcello Locatelli ${ }^{5}$ D, Angela Tartaglia ${ }^{4}$, Syafiq Asnawi Zainal Abidin ${ }^{6}$ and \\ Nafees Ahemad 1,7,8,*
}

1 School of Pharmacy, Monash University Malaysia, Jalan Lagoon Selatan, Bandar Sunway 47500, Malaysia; Thet.Thet.Htar@monash.edu

2 Institute of Pharmaceutical Sciences (IPS), University of Veterinary \& Animal Sciences (UVAS), Lahore 54000, Pakistan

3 Jeffrey Cheah School of Medicine and Health Sciences, Monash University Malaysia, Jalan Lagoon Selatan, Bandar Sunway 47500, Malaysia; Rakesh.Naidu@monash.edu

4 Department of Biology, Faculty of Science, Selcuk University, 42250 Konya, Turkey; gokhanzengin@selcuk.edu.tr (G.Z.); angela.tartaglia@unich.it (A.T.)

5 Department of Pharmacy, University 'G. d'Annunzio" of Chieti-Pescara, 66100 Chieti, Italy; m.locatelli@unich.it

6 Liquid Chromatography Mass Spectrometry (LCMS) Platform, Monash University, Jalan Lagoon Selatan, Bandar Sunway 47500, Malaysia; syafiq.asnawi@monash.edu

7 Tropical Medicine and Biology Multidisciplinary Platform, Monash University Malaysia, Jalan Lagoon Selatan, Bandar Sunway 47500, Malaysia

8 Global Asia in the 21st Century (GA21) Multidisciplinary Research Platform, Monash University, Melbourne VIC 3800, Australia

* Correspondence: hammad.saleem@uvas.edu.pk or hammad.saleem@monash.edu (H.S.); nafees.ahemad@monash.edu (N.A.)

Received: 23 April 2020; Accepted: 21 June 2020; Published: 29 June 2020

Abstract: The current research work is an endeavor to study the chemical profiling and enzyme-inhibition potential of different polarity solvent ( $n$-hexane, dichloromethane-DCM and methanol- $\mathrm{MeOH}$ ) extracts from the aerial and stem parts of Buxus papillosa C.K. Schneid. All the extracts were analyzed for HPLC-PDA phenolic quantification, while both (aerial and stem) DCM extracts were studied for UHPLC-MS phytochemical composition. The inhibitory activity against the clinically important enzymes having crucial role in different pathologies like skin diseases (tyrosinase), inflammatory problems (lipoxygenase-LOX) and diabetes mellitus ( $\alpha$-amylase) were studied using standard in vitro bioassays. The DCM extracts upon UHPLC-MS analysis conducted in both negative and positive ionization modes has led to the tentative identification of 52 important secondary metabolites. Most of these belonged to the alkaloid, flavonoid, phenolic and triterpenoid classes. The HPLC-PDA polyphenolic quantification identified the presence of 10 phenolic compounds. Catechin was present in significant amounts in aerial-MeOH $(7.62 \pm 0.45 \mu \mathrm{g} / \mathrm{g}$ extract $)$ and aerial-DCM $(2.39 \pm 0.51-\mu \mathrm{g} / \mathrm{g}$ extract) extracts. Similarly, higher amounts of epicatechin $(2.76 \pm 0.32-\mu \mathrm{g} / \mathrm{g}$ extract $)$ and $p$-hydroxybenzoic acid $(1.06 \pm 0.21 \mu \mathrm{g} / \mathrm{g}$ extract) were quantified in aerial-DCM and stem-MeOH extracts, respectively. Likewise, all the extracts exhibited moderate inhibition against all the tested enzymes. These findings explain the wide usage of this plant in folklore medicine and suggest that it could be further studied as an origin of novel bioactive phytocompounds and for the designing of new pharmaceuticals.

Keywords: Buxus papillosa; phenolic compounds; antioxidant; tyrosinase; amylase; lipoxygenase 


\section{Introduction}

The conventional herbal medicinal system is playing a central role to prevent and treat different diseases since time immemorial, and these medicinal herbs are rich sources for the discovery of novel drugs [1]. During the past few decades, the number of prescribed medicines which have been developed from different higher plants are estimated to have an expansion of about $25 \%$. It is also noteworthy that, if traditional medicines are used in a scientific way, they can be considered safer than the modern medicines [2,3]. Since ancient times, these plant derived natural products are regarded as the origin of modern drugs. Currently, many of these natural phytocompounds have been scientifically approved as antioxidant, antimicrobial and, anticancer agents [4-6]. Natural products obtained from medicinal plants are receiving much more attention nowadays, and are also considered worldwide as a worthy source for the development of new drug molecules [7]. Understandingly, it is reported that the plant based natural medicines are conquering the pharmaceutical industries, and about 1300 herbal drugs have been utilized in Europe. Likewise, in USA until 2005, the number of natural based drugs was comparatively higher among the total prescribed drugs [8]. Some of the recent studies have highlighted that in the developed countries, about $80 \%$ of the population is still depending upon traditional drug therapies for the treatment of common ailments; one-fourth of the prescribed drugs in these countries are derived from natural flora [9]. Keeping in view this upsurge in herbal therapies and natural product usage, the secondary metabolites and/or phytochemicals of natural sources are currently being investigated and explored for the discovery of novel drug leads [10]. With this frame of reference, most of the scientific community have directed their research interests towards characterization and pharmacological effects of medicinal plants and their isolated chemical constituents [11,12]. Right now, unexplored medicinal plants from various folklore medicinal systems could be taken into consideration as an inspiring sources for bioactive phytochemicals for drug designing as well as functional food advancement plans [13].

The genus Buxus (family: Buxaceae) is commonly known as boxwood. This genus is comprised of about 70 different species and is native to China, Europe, America and Asia among other countries. Most of the plants of this genus are distributed in northern America and Eurasia, such as Pakistan, Turkey and China [14-16]. This genus is known to contain many important classes of phytochemicals including steroids, alkaloids, terpenoids, among others [17-19]. Most of the plant species of this genus have been reported folklore uses for the treatment of skin infections, malaria, human immunodeficiency virus (HIV) infections, cancer, depression, tuberculosis, etc. [20-22].

Buxus papillosa C.K. Schneid. Most commonly called as Shamshad is a shrubby plant and is commonly found in the northern areas of Pakistan. The different extracts of these plants have been extensively utilized in the indigenous medicinal system for treating common ailments including skin infections, malaria and rheumatism [23]. As continuation of our plant based research, we have previously reported the phytochemical composition (UHPLC-MS analysis) and pharmacological effects of aerial and stem parts of this plant [24]. As the data on the chemical profiling of some of the polarity solvent extracts is still missing, therefore, this study was conducted to provide in-depth phytochemical profiling and enzyme inhibitory potential of this plant. The phytochemical phenolic composition was established by determining high-pressure liquid chromatography photodiode array (HPLC-PDA) method, while the DCM extracts were analyzed for ultra-high performance liquid chromatography-mass spectrometry (UHPLC-MS) analysis. All the extracts were also analyzed for inhibitory activity for the clinically important enzymes having important roles in common ailments, for-example, diabetes mellitus ( $\alpha$-amylase), inflammation (LOX) and skin diseases (tyrosinase). The current research work may be considered as a foremost report on such phytochemical and enzyme inhibition activities of aerial and stem parts of this plant. 


\section{Results and Discussion}

\subsection{HPLC-PDA Analysis}

Phenolic secondary metabolites are considered as one of the abundant phytocompounds in plants possessing different pharmacological effects and also regarded as the most common antioxidants that are present in human diet [25]. The phenolic compounds have been previously appraised for different biological assays including antioxidants, anticancer, antimicrobial and anti-inflammatory. Similarly, flavonoids are also most common group of phenolics and regarded as natural bioactive molecules in order to design novel bioactive products [26]. The present research wok describes the HPLC-PDA polyphenolic quantification for the $n$-hexane, DCM and $\mathrm{MeOH}$ extracts from B. Papillosa aerial and stem parts. A list of 22 important standard phenolic phytochemicals were tested for their quantification, however, all the studied extracts were found to contain 10 of these compounds. The results of these quantified phenolics is presented in Table 1 and their chemical structures are shown in Figure 1. Likewise, the HPLC chromatograms for each individual extract is given in the Supplementary Material section (Figures S1-S5). From the results, it could be seen that B. papillosa aerial-DCM extract was containing a higher amount of phenolics in comparison with other extracts. The highest amounts of catechin $(7.62 \pm 0.45 \mu \mathrm{g} / \mathrm{g}$ extract) was found in the aerial-MeOH extract, while naringin was detected as BLD i.e., below limit of detection $\cdot 1 \mu \mathrm{g} / \mathrm{mL}$ ) in this extract (Figure S1). Likewise, the aerial-DCM extract was containing the catechin $(2.39 \pm 0.51 \mu \mathrm{g} / \mathrm{g}$ extract $)$, epicatechin $(2.76 \pm 0.32 \mu \mathrm{g} / \mathrm{g}$ extract $)$, syringic acid $(0.77 \pm 0.06 \mu \mathrm{g} / \mathrm{g}$ extract), benzoic acid $(0.47 \pm 0.04 \mu \mathrm{g} / \mathrm{g}$ extract) and vanillic acid (BLD) (Figure S2). Interestingly, none of the tested phenolic standards were present in the aerial-hexane extract which may be due to the non-polar nature of this extract. Similarly, $p$-hydroxybenzoic acid $(1.06 \pm 0.21$ $\mu \mathrm{g} / \mathrm{g}$ extract), 3-hydroxy benzoic acid $(0.59 \pm 0.06 \mu \mathrm{g} / \mathrm{g}$ extract) and gallic acid (BLQ-below limit of quantification, i.e., $<0.2 \mu \mathrm{g} / \mathrm{mL}$ ) were quantified in the stem-MeOH extract (Figure S3). The stem-DCM extract was found to contain two compounds including syringic acid $(0.24 \pm 0.02 \mu \mathrm{g} / \mathrm{g}$ extract) and 3-hydroxy-4-methoxy benzaldehyde $(0.38 \pm 0.04 \mu \mathrm{g} / \mathrm{g}$ extract) (Figure S4). Naringin $(0.45 \pm 0.04 \mu \mathrm{g} / \mathrm{g}$ extract) was the only phenolic detected in stem-hexane extract (Figure S5). Overall, this phenolic profiling confirms the presence of important secondary metabolites, so these plant extracts can be explored further for the isolation bioactive molecules having therapeutic importance.

Table 1. HPLC phenolic quantification of Buxus papillosa extracts.

\begin{tabular}{ccccccc}
\hline $\begin{array}{c}\text { Phenolic Compounds } \\
\text { ( } \mu \mathrm{g} / \mathrm{g} \text { Sample) }\end{array}$ & \multicolumn{5}{c}{ B. papillosa Extracts } \\
\cline { 2 - 7 } & Aerial-MeOH & Aerial-DCM & Aerial-Hexane Stem-MeOH & Stem-DCM & Stem-Hexane \\
\hline Gallic acid & nd & nd & nd & BLQ & nd & nd \\
Catechin & $7.62 \pm 0.45$ & $2.39 \pm 0.51$ & nd & nd & nd & nd \\
p- hydroxybenzoic acid & nd & nd & nd & $1.06 \pm 0.21$ & nd & nd \\
Vanillic acid & nd & BLD & nd & nd & nd & nd \\
Epicatechin & nd & $2.76 \pm 0.32$ & nd & nd & nd & nd \\
Syringic acid & nd & $0.77 \pm 0.06$ & nd & nd & $0.24 \pm 0.02$ & nd \\
3-hydroxy benzoic acid & nd & nd & nd & $0.59 \pm 0.06$ & nd & nd \\
3-hydroxy-4-methoxy benzaldehyde & nd & nd & nd & nd & $0.38 \pm 0.04$ & nd \\
Naringin & BLD & nd & nd & nd & nd & $0.45 \pm 0.04$ \\
Benzoic acid & nd & $0.47 \pm 0.04$ & nd & nd & nd & nd \\
\hline
\end{tabular}

nd: Not detected; BLD: below limit of detection $(<0.1 \mu \mathrm{g} / \mathrm{mL})$; BLQ: below limit of quantification $(<0.2 \mu \mathrm{g} / \mathrm{mL})$; Chlorogenic acid, quercetin, $p$-coumaric acid, rutin, sinapinic acid, naringenin, $t$-ferulic acid, harpagoside, 2,3-di-methoxy benzoic acid, $o$-coumaric acid, $t$-cinnamic acid and carvacrol were not present in all the four extracts.

\subsection{UHPLC-MS Secondary Metabolites Analysis}

The analysis of phytochemical composition of plant extracts is given much importance because it is not justifiable to evaluate the biologic properties of an extract devoid of its chemical composition. Moreover, the pharmacological effects of a medicinal plant is directly depending on the bioactive compounds that are present naturally in the plants. As a whole, phytochemical profiling is mandatory for making an accurate estimation of the biologic properties of plant extracts [27]. In the current research, the UHPLC-MS analysis (in both positive and negative ionization modes) of DCM extracts of B. papillosa aerial and stem parts was performed. As indicated in Table 2, the UHPLC-MS phytochemical 
composition of B. papillosa aerial-DCM extract have tentatively identified 29 different phytocompounds. Their total ion chromatograms (TICs) are shown in Figure 2.

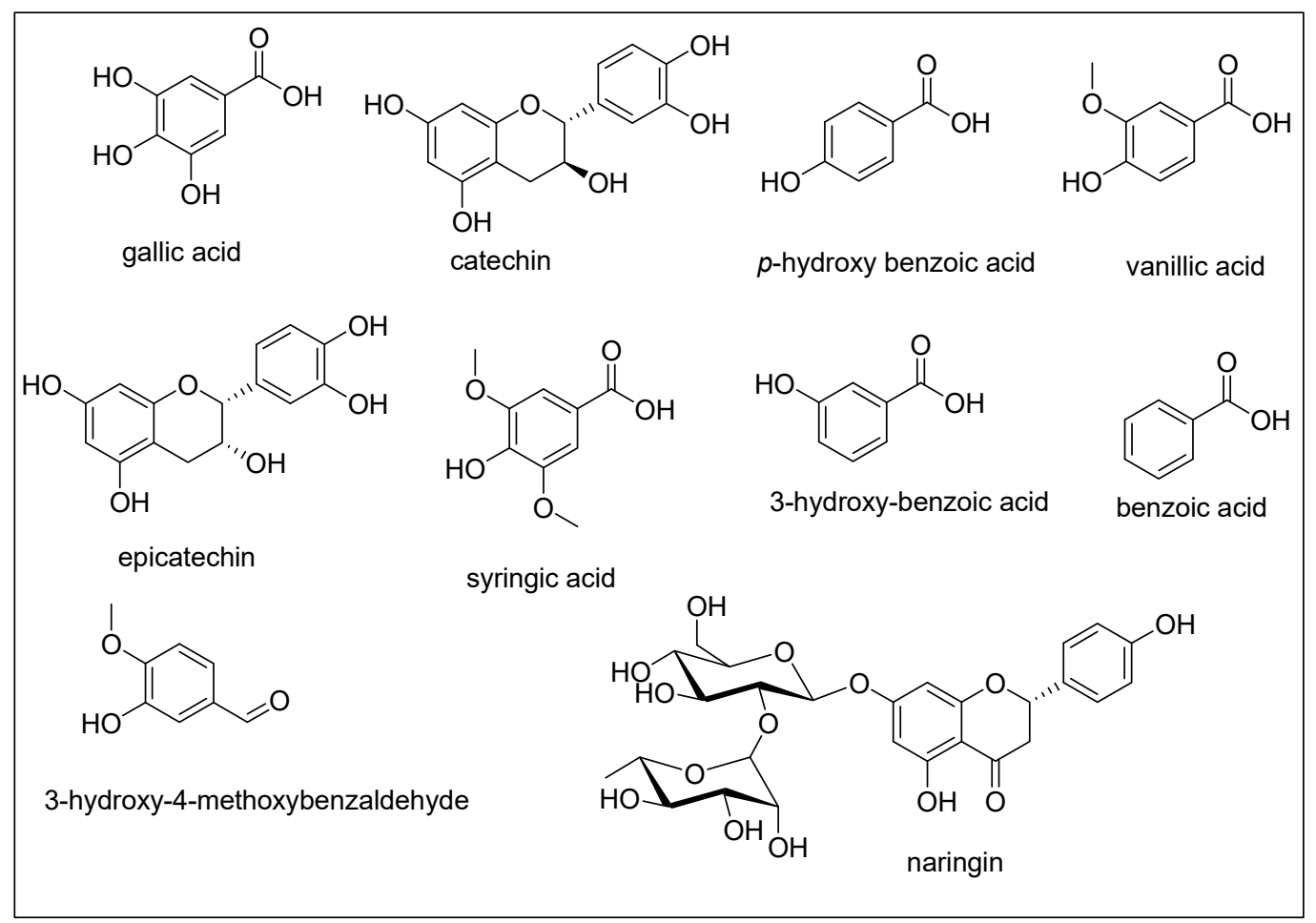

Figure 1. Phenolic compounds quantified in different extracts of B. papillosa.

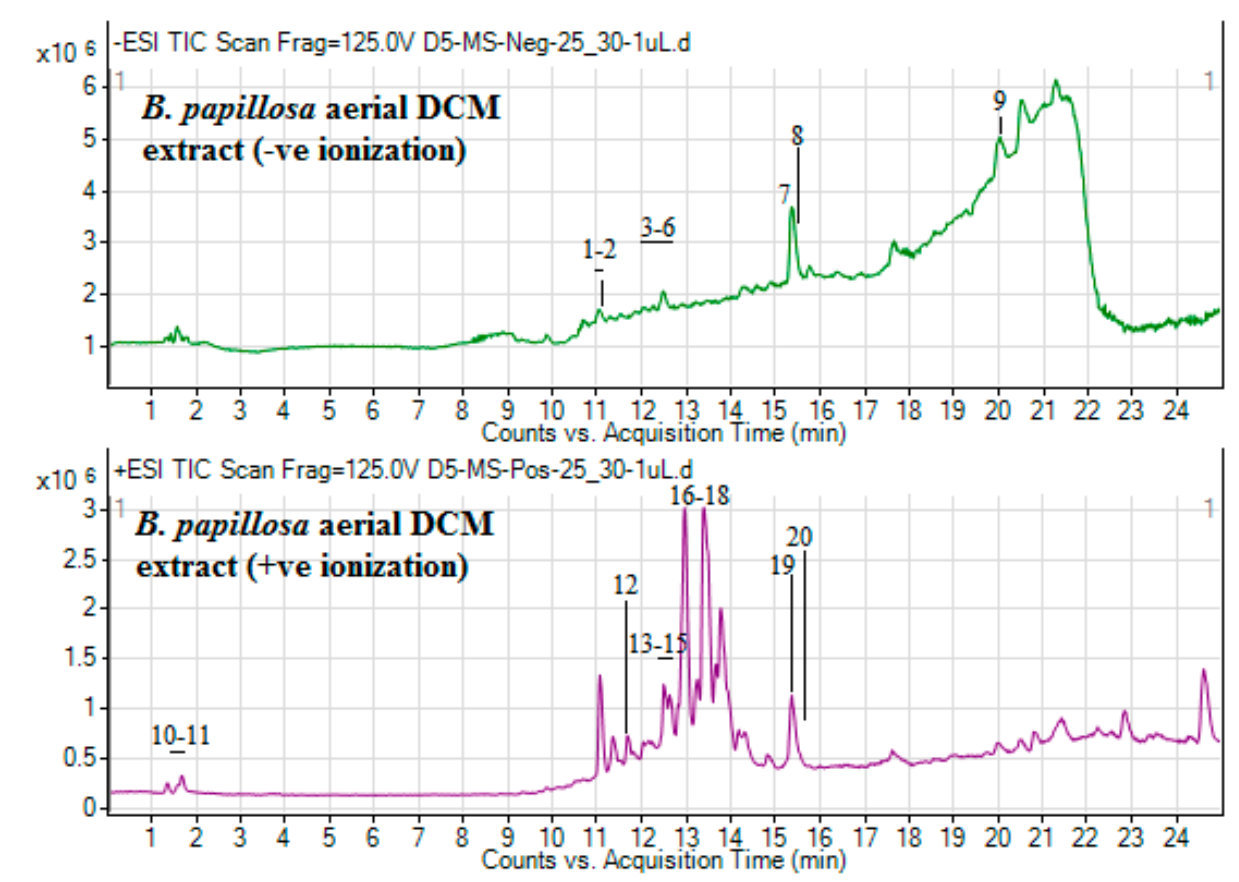

Figure 2. UHPLC-MS total ion chromatograms (TICs) of DCM extract of B. papillosa aerial parts. 
Table 2. Ultra-high performance liquid chromatography-mass spectrometry (UHPLC-MS) secondary metabolites composition of B. papillosa aerial dichloromethane (DCM) extract (negative and positive ionization mode).

\begin{tabular}{|c|c|c|c|c|c|c|}
\hline S. No & RT (min) & B. Peak $(m / z)$ & Tentative Identification & Comp. Class & Mol. Mass & Mol. Formula \\
\hline \multicolumn{7}{|c|}{ Negative Ionization } \\
\hline 1 & 11.014 & 579.2159 & (+)-Syringaresinol O-beta-D-glucoside & Phenolic & 580.2159 & $\mathrm{C}_{28} \mathrm{H}_{36} \mathrm{O}_{13}$ \\
\hline 2 & 11.029 & 415.2045 & Ethyl 7-epi-12-hydroxyjasmonate glucoside & Glucoside & 416.2045 & $\mathrm{C}_{20} \mathrm{H}_{32} \mathrm{O}_{9}$ \\
\hline 3 & 12.041 & 577.2003 & Podorhizol beta-- - glucoside & Glucoside & 578.2003 & $\mathrm{C}_{28} \mathrm{H}_{34} \mathrm{O}_{13}$ \\
\hline 4 & 12.435 & 551.1489 & 1-Hydroxy-3-methoxy-7-primeverosyloxyxanthone & Xanthone glycosides & 552.1489 & $\mathrm{C}_{25} \mathrm{H}_{28} \mathrm{O}_{14}$ \\
\hline 5 & 12.495 & 581.1594 & 5,7,3', $4^{\prime}$-Tetrahydroxyflavanone7-alpha-L-arabinofuranosyl-(1->6)-glucoside & Flavonoid & 582.1594 & $\mathrm{C}_{26} \mathrm{CH}_{30} \mathrm{O}_{15}$ \\
\hline 6 & 12.695 & 137.0321 & $p$-Salicylic acid & Phenolic & 138.0321 & $\mathrm{C}_{7} \mathrm{H}_{6} \mathrm{O}_{3}$ \\
\hline 7 & 15.375 & 343.0908 & Wightin & Flavonoid & 344.0908 & $\mathrm{C}_{18} \mathrm{H}_{16} \mathrm{O}_{7}$ \\
\hline 8 & 15.554 & 373.1002 & 8-Methoxycirsilineol & Flavonoid & 374.1002 & $\mathrm{C}_{19} \mathrm{H}_{18} \mathrm{O}_{8}$ \\
\hline 9 & 20.018 & 681.4297 & Cyclopassifloside II & Triterpene & 682.4297 & $\mathrm{C}_{37} \mathrm{H}_{62} \mathrm{O}_{11}$ \\
\hline \multicolumn{7}{|c|}{ Positive ionization } \\
\hline 10 & 1.589 & 160.09 & $\begin{array}{ll}\text { Calystegine A7 } \\
\end{array}$ & Alkaloid & 159.09 & $\mathrm{C}_{7} \mathrm{H}_{13} \mathrm{NO}_{3}$ \\
\hline 11 & $\begin{array}{l}1.1099 \\
1.687\end{array}$ & 144.0948 & 3beta,6beta-Dihydroxynortropane & $\begin{array}{l}\text { Alkaloid } \\
\text { Alkal }\end{array}$ & $\begin{array}{c}159.09 \\
143.0948\end{array}$ & $\begin{array}{ll}7 \mathrm{H}_{13} \\
\mathrm{C}_{7} \mathrm{H}_{13} \mathrm{NO}_{2}\end{array}$ \\
\hline 12 & 11.73 & 197.1101 & 4-(2-hydroxypropoxy)-3,5-dimethyl-Phenol & Phenol & 196.1101 & $\mathrm{C}_{11} \mathrm{H}_{16} \mathrm{O}_{3}$ \\
\hline 13 & 12.431 & 507.1432 & Morin 3,7,4'-trimethyl ether 2'-glucoside & Glucoside & 506.1432 & $\mathrm{C}_{24} \mathrm{H}_{26} \mathrm{O}_{12}$ \\
\hline 14 & 12.496 & 537.1532 & Dalpaniculin & Flavonoid & 536.1532 & $\mathrm{C}_{25} \mathrm{H}_{28} \mathrm{O}_{13}$ \\
\hline 15 & 12.683 & 427.3616 & $\mathrm{Nb}$-Stearoyltryptamine & Alkaloid & 426.3616 & $\mathrm{C}_{28} \mathrm{H}_{46} \mathrm{~N}_{2} \mathrm{O}$ \\
\hline 16 & 13.393 & 523.4061 & Panaxydol linoleate & Polyacetylenic & 522.4061 & $\mathrm{C}_{35} \mathrm{H}_{54} \mathrm{O}_{3}$ \\
\hline 17 & 13.459 & 525.4223 & Flavidulol D & $\begin{array}{l}\text { aervative } \\
\text { Phenol }\end{array}$ & 524.4223 & $\mathrm{C}_{35} \mathrm{H}_{56} \mathrm{O}_{3}$ \\
\hline 18 & 13.498 & 362.3339 & 2,4,8-Eicosatrienoic acid isobutylamide & Alkaloid & 361.3339 & $\mathrm{C}_{24} \mathrm{H}_{43} \mathrm{NO}$ \\
\hline 19 & 15.383 & 345.09 & Wightin & Flavonoid & 344.09 & $\mathrm{C}_{18} \mathrm{H}_{16} \mathrm{O}_{7}$ \\
\hline 20 & 15.566 & 375.1005 & 8-Methoxycirsilineol & Flavonoid & 374.1005 & $\mathrm{C}_{19} \mathrm{H}_{18} \mathrm{O}_{8}$ \\
\hline
\end{tabular}

RT: retention time; B: peak: base peak. 
The classes of compounds profiled were majorly flavonoid $\left(7,3^{\prime}, 4^{\prime}\right.$-tetrahydroxyflavanone 7-alpha-L-arabinofuranosyl-(1->6)-glucoside, wightin, 8-methoxycirsilineol and dalpaniculin), alkaloid (calystegine A7, 3beta,6beta-dihydroxynortropane, Nb-stearoyltryptamine and 2,4,8-eicosatrienoic acid isobutylamide), phenolic (+)-syringaresinol O-beta-D-glucoside, p-salicylic acid, 4-(2-hydroxypropoxy)-3,5-dimethyl-phenol and flavidulol D) and glucoside (ethyl 7-epi-12-hydroxyjasmonate glucoside, podorhizol beta-D-glucoside and morin 3,7,4'-trimethyl ether 2'-glucoside) derivatives. Three other compounds 1-hydroxy-3-methoxy-7-primeverosyloxyxanthone (xanthone glycosides derivative), panaxydol linoleate (polyacetylenic derivative) and cyclopassifloside II (triterpene derivative) were also tentatively identified. Likewise, the tentative secondary metabolites composition of stem-DCM extract as conducted by UHPLC-MS analysis is presented in Table 3, has revealed the tentative presence of a total of 32 phytocompounds. The TICs for this extract is shown in Figure 3. As presented in Table 3, most of these phytocompounds were belonging to alkaloid and flavonoid groups of secondary metabolites. The alkaloids tentatively detected were 14,19-dihydroaspidospermatine, prosopinine, uplandicine, cyclobuxine D, cyclovirobuxine C, terminaline, solanocapsine, evocarpine, prosopinine and camptothecin, whereas, the flavonoids were chrysosplenoside D, melisimplexin, wightin, 8-methoxycirsilineol, dalpaniculin and melisimplexin. Likewise, the other compounds identified were belonging to triterpene/triterpenoid, organic acid, phloroglucinol, polyacetylenic, phenol, carotenoid, vitamin, sesquiterpenoid and vitamin derivatives (Table 3). To our knowledge, this is the initial tentative UHPLC-MS phytochemical study for the DCM extracts of this plant.

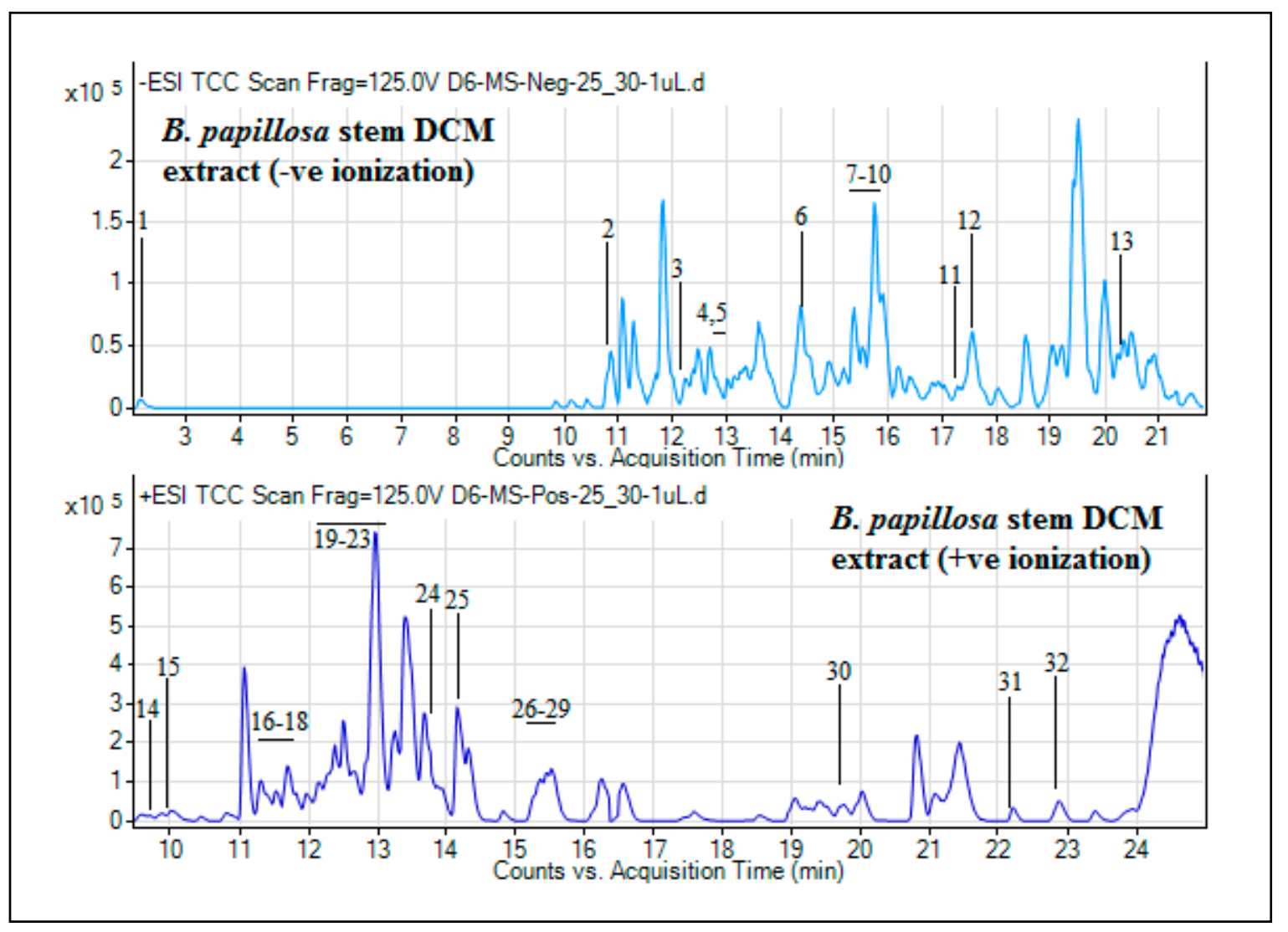

Figure 3. UHPLC-MS total ion chromatograms (TICs) of DCM extract of B. papillosa stem parts. 
Table 3. UHPLC-MS secondary metabolites composition of B. papillosa stem DCM extract (negative and positive ionization mode).

\begin{tabular}{|c|c|c|c|c|c|c|}
\hline S. No & RT (min) & B. Peak $(m / z)$ & Tentative Identification & Comp. Class & Mol. Mass & Mol. Formula \\
\hline \multicolumn{7}{|c|}{ Negative ionization } \\
\hline 1 & 2.176 & 192.027 & Citric acid & Organic acid & 192.027 & $\mathrm{C}_{6} \mathrm{H}_{8} \mathrm{O}_{7}$ \\
\hline 2 & 10.888 & 174.0892 & Suberic acid & Organic acid & 174.0892 & $\mathrm{C}_{8} \mathrm{H}_{14} \mathrm{O}_{4}$ \\
\hline 3 & 12.27 & 522.1391 & Chrysosplenoside D & Flavonoid & 522.1391 & $\mathrm{C}_{24} \mathrm{H}_{26} \mathrm{O}_{13}$ \\
\hline 4 & 12.834 & 386.1011 & Melisimplexin & Flavonoid & 386.1011 & $\mathrm{C}_{20} \mathrm{H}_{18} \mathrm{O}_{8}$ \\
\hline 5 & 12.87 & 588.401 & 22-Angeloyltheasapogenol A & Triterpenoid & 588.401 & $\mathrm{C}_{35} \mathrm{H}_{56} \mathrm{O}_{7}$ \\
\hline 6 & 14.388 & 340.2158 & 14,19-Dihydroaspidospermatine & Alkaloid & 340.2158 & $\mathrm{C}_{21} \mathrm{H}_{28} \mathrm{~N}_{2} \mathrm{O}_{2}$ \\
\hline 7 & 15.262 & 287.2465 & Prosopinine & Alkaloid & 287.2465 & $\mathrm{C}_{16} \mathrm{H}_{33} \mathrm{NO}_{3}$ \\
\hline 8 & 15.375 & 344.0901 & Wightin & Flavonoid & 344.0901 & $\mathrm{C}_{18} \mathrm{H}_{16} \mathrm{O}_{7}$ \\
\hline 9 & 15.559 & 374.0998 & 8-Methoxycirsilineol & Flavonoid & 374.0998 & $\mathrm{C}_{19} \mathrm{H}_{18} \mathrm{O}_{8}$ \\
\hline 10 & 15.776 & 357.1804 & Uplandicine & Alkaloid & 357.1804 & $\mathrm{C}_{17} \mathrm{H}_{27} \mathrm{NO}_{7}$ \\
\hline 11 & 17.285 & 488.3486 & Arjunolic acid & Triterpenoid & 488.3486 & $\mathrm{C}_{30} \mathrm{H}_{48} \mathrm{O}_{5}$ \\
\hline 12 & 17.573 & 472.3548 & Lucidumol A & Triterpene & 472.3548 & $\mathrm{C}_{30} \mathrm{H}_{48} \mathrm{O}_{4}$ \\
\hline 13 & 20.24 & 486.3345 & Quillaic acid & Triterpene & 486.3345 & $\mathrm{C}_{30} \mathrm{H}_{6} \mathrm{O}_{5}$ \\
\hline \multicolumn{7}{|c|}{ Positive ionization } \\
\hline 14 & 9.584 & 387.3314 & Cyclobuxine D & Alkaloid & 386.3314 & $\mathrm{C}_{25} \mathrm{H}_{42} \mathrm{~N}_{2} \mathrm{O}$ \\
\hline 15 & 10.046 & 417.377 & Cyclovirobuxine $\mathrm{C}$ & Alkaloid & 416.377 & $\mathrm{C}_{27} \mathrm{H}_{48} \mathrm{~N}_{2} \mathrm{O}$ \\
\hline 16 & 11.358 & 364.3144 & Terminaline & Alkaloid & 363.3144 & $\mathrm{C}_{23} \mathrm{H}_{41} \mathrm{NO}_{2}$ \\
\hline 17 & 11.436 & 553.3897 & Furohyperforin & Phloroglucinol & 552.3897 & $\mathrm{C}_{35} \mathrm{H}_{52} \mathrm{O}_{5}$ \\
\hline 18 & 11.735 & 197.1103 & 4-(2-Hydroxypropoxy)-3,5-dimethyl-phenol & Phenol & 196.1103 & $\mathrm{C}_{11} \mathrm{H}_{16} \mathrm{O}_{3}$ \\
\hline 19 & 12.115 & 431.3552 & Solanocapsine & Alkaloid & 430.3552 & $\mathrm{C}_{27} \mathrm{H}_{46} \mathrm{~N}_{2} \mathrm{O}_{2}$ \\
\hline 20 & 12.499 & 537.1533 & Dalpaniculin & Flavonoid & 536.1533 & $\mathrm{C}_{25} \mathrm{H}_{28} \mathrm{O}_{13}$ \\
\hline 21 & 12.743 & 340.2561 & Evocarpine & Alkaloid & 339.2561 & $\mathrm{C}_{23} \mathrm{H}_{33} \mathrm{NO}$ \\
\hline 22 & 12.923 & 523.4056 & Panaxydol linoleate & $\begin{array}{l}\text { Polyacetylenic } \\
\text { derivative }\end{array}$ & 522.4056 & $\mathrm{C}_{35} \mathrm{H}_{54} \mathrm{O}_{3}$ \\
\hline 23 & 13.046 & 387.101 & Melisimplexin & Flavonoid & 386.101 & $\mathrm{C}_{20} \mathrm{H}_{18} \mathrm{O}_{8}$ \\
\hline 24 & 13.899 & 583.4064 & 4-Ketolutein D & Carotenoid & 582.4064 & $\mathrm{C}_{40} \mathrm{H}_{54} \mathrm{O}_{3}$ \\
\hline 25 & 14.252 & 230.2405 & Xestoaminol C & Vitamin & 229.2405 & $\mathrm{C}_{14} \mathrm{H}_{31} \mathrm{NO}$ \\
\hline 26 & 15.264 & 288.2458 & Prosopinine & Alkaloid & 287.2458 & $\mathrm{C}_{16} \mathrm{H}_{33} \mathrm{NO}_{3}$ \\
\hline 27 & 15.375 & 345.0903 & Wightin & Flavonoid & 344.0903 & $\mathrm{C}_{18} \mathrm{H}_{16} \mathrm{O}_{7}$ \\
\hline 28 & 15.473 & 318.1262 & Hemanthidine & Alkaloid & 317.1262 & $\mathrm{C}_{17} \mathrm{H}_{19} \mathrm{NO}_{5}$ \\
\hline 29 & 15.563 & 375.1002 & 8-Methoxycirsilineol & Flavonoid & 374.1002 & $\mathrm{C}_{19} \mathrm{H}_{18} \mathrm{O}_{8}$ \\
\hline 30 & 19.752 & 279.1531 & Emmotin A & Sesquiterpenoid & 278.1531 & $\mathrm{C}_{16} \mathrm{H}_{22} \mathrm{O}_{4}$ \\
\hline 31 & 22.219 & 349.1101 & Camptothecin & Alkaloid & 348.1101 & $\mathrm{C}_{20} \mathrm{H}_{16} \mathrm{~N}_{2} \mathrm{O}_{4}$ \\
\hline 32 & 22.85 & 593.2707 & Pheophorbide a & $\begin{array}{l}\text { Chlorophyll } \\
\text { derivative }\end{array}$ & 592.2707 & $\mathrm{C}_{35} \mathrm{H}_{36} \mathrm{~N}_{4} \mathrm{O}_{5}$ \\
\hline
\end{tabular}

RT: Retention time; B. peak: Base peak. 


\subsection{Enzyme Inhibition Potential}

In order to have an effective control and to manage the worldwide health related problem, inhibition of the important enzyme directly related with the common pathologies may be studied as one of the prime therapeutic strategy [28]. In the present research work, we have evaluated the inhibitory activity of B. papillosa aerial and stem extracts for their inhibition potential against tyrosinase, $\alpha$-amylase, and LOX enzymes which are considered to be important enzymes playing important role in common disorders, i.e., skin problems, diabetes and inflammatory disorders. The results of enzyme inhibition assays are gathered in Table 4.

Table 4. Enzyme inhibition potential of aerial and stem extracts of B. papillosa.

\begin{tabular}{|c|c|c|c|c|}
\hline \multirow[b]{2}{*}{ Extracts } & \multirow{2}{*}{$\begin{array}{c}\text { Tyrosinase } \\
\text { (mg KAE/g Extract) }\end{array}$} & \multirow{2}{*}{$\begin{array}{c}\alpha \text {-Amylase } \\
\text { (mmol ACAE/g Extract) }\end{array}$} & \multicolumn{2}{|c|}{ Lipoxygenase } \\
\hline & & & $\begin{array}{l}\text { (\% Inhibition; } \\
0.5 \mathrm{mg} / \mathrm{mL} \text { ) }\end{array}$ & $\mathrm{IC}_{50}(\mu \mathrm{g} / \mathrm{mL})$ \\
\hline Aerial-MeOH & $25.87 \pm 0.28^{b, c}$ & $0.08 \pm 0.01^{\mathrm{c}}$ & $13.4 \pm 1.5$ & $>500 * *$ \\
\hline Aerial-DCM & $24.40 \pm 0.52^{\mathrm{d}}$ & $0.04 \pm 0.01 \mathrm{~d}$ & $12.3 \pm 1.4$ & $>500$ \\
\hline Aerial-hexane & $25.15 \pm 0.26^{\mathrm{c}, \mathrm{d}}$ & $0.13 \pm 0.01 \mathrm{a}$ & $42.6 \pm 1.5$ & $>500$ \\
\hline Stem-MeOH & $25.99 \pm 0.27^{b}$ & $0.11 \pm 0.01^{\mathrm{b}}$ & $9.4 \pm 1.6$ & $>500$ \\
\hline Stem-DCM & $27.14 \pm 0.17^{\mathrm{a}}$ & $0.11 \pm 0.01 \mathrm{a}, \mathrm{b}$ & $4.7 \pm 1.7$ & $>500$ \\
\hline Stem-hexane & $26.62 \pm 0.05^{\mathrm{a}, \mathrm{b}}$ & $0.12 \pm 0.01^{a}, \mathrm{~b}$ & $12.5 \pm 1.6$ & $>500$ \\
\hline Quercetin & nt & nt & $89.2 \pm 0.6$ & $2.3 \pm 0.3(\mu \mathrm{M})$ \\
\hline
\end{tabular}

KAE: Kojic acid equivalent; ACAE: acarbose equivalent; All the results are presented as means \pm S.D. different; nt: not tested; ** Value of $\mathrm{IC}_{50}$ was above $500 \mu \mathrm{g} / \mathrm{mL}$. Different letters indicate significant differences in the extracts $(p<0.05)$.

A copper-containing enzyme, i.e., tyrosinase is considered as an important enzyme because of its important role in the biosynthesis of melanin [29]. All the extracts were tested for the tyrosinase inhibition assay and the results are given in Table 4. From the results, it was noted that all extracts presented moderate activity. Among these, the stem-DCM extract was the most active one with inhibition of $27.14 \mathrm{mg} \mathrm{KAE} / \mathrm{g}$ extract. Similarly, the $\alpha$-amylase enzyme imparts an important role to control glycemia and to manage type 2 diabetes, the control of postprandial glycemia is regarded as an effective strategy [30]. As presented in Table 4, a weak anti- $\alpha$-amylase activity was recorded with both the hexane extracts showing higher inhibition (aerial-hexane; 0.13-mmol ACAE/g extract; stem hexane; 0.12-mmol ACAE/g extract) compared with other extracts. Likewise, the enzyme lipoxygenase is considered important in the process of inflammation, specifically in the leukotrienes biochemical processes, which are considered to be the major triggers responsible for inflammation and allergic reactions [31]. The results of LOX inhibition assay are given in Table 4, and it was seen that the aerial-hexane extract showed higher percentage inhibition of $42.6 \%$, while the other extracts presented weak inhibition percentage. Overall, all the extracts exhibited moderate inhibition potential against the tested enzymes, and this observed activity may be correlated with phytochemical profiling of this plant extracts specifically phenolic and flavonoid classes of compounds, as previously a positive connection was noted among enzyme inhibition potential and these phytocompounds [32]. The research reports on such enzyme inhibition assays is lacking specifically for this plant species, thus the current preliminary results may serve as a triggering point in order to extensively explore this plant for the discovery of enzyme inhibitory compounds of natural origin. However, further research work in order to isolate the targeted compounds which are responsible for the observed enzyme inhibitory activities is highly recommended.

\section{Materials and Methods}

\subsection{Plant Material and Extraction}

B. papillosa aerial and stem parts were collected from the peripheral areas of Malakand, Pakistan. The plant was authenticated by Dr. Abdul-Rehman Niazi (Incharge Herbarium), Department of Botany, Punjab University Lahore, Pakistan. For future reference, a plant specimen voucher number, i.e., LAH \# 
7517 was deposited at Department of Botany herbarium Punjab University Lahore, Pakistan. Both the plant parts were placed for shade drying, and after that grounded into fine powder. The powdered plant material was extracted by the process of maceration (at room temperature) using $n$-hexane, DCM and $\mathrm{MeOH}$, successively for 3 days with each solvent. The solvent was evaporated under reduced pressure in the rotary evaporator to afford the concentrated extracts.

\subsection{Phytochemical Composition}

The HPLC-PDA polyphenolic quantification of all the extracts was carried out in order to quantify 22 phenolic standards accordingly standard methods as reported previously [33,34]. Likewise, the tentative secondary metabolites phytochemical composition of the DCM extracts was studies by previously described UHPLC-MS analysis [35]. The details of these both the methods are given in Supplementary section.

\subsection{Enzyme Assays}

The inhibitory assays of the studied extracts were conducted against three enzymes, namely $\alpha$-amylase, tyrosinase and lipoxygenase. All the enzyme assays were conducted utilizing previously reported standard methods [29,36,37]. Acarbose, kojic acid and quercetin was uses as standards for $\alpha$-amylase, tyrosinase and lipoxygenase enzymes, respectively. The $\alpha$-amylase and tyrosinase inhibition activity were expresses as acarbose equivalents (mmol ACE/g extract) and kojic acid equivalents (mg KAE/g extract), respectively. Whereas, for lipoxygenase enzyme, the percentage inhibition was calculated and the $\mathrm{IC}_{50}$ value was also recorded using quercetin as positive control. The details of all these assays is provided in Supplementary file.

\subsection{Statistical Analysis}

All the assays were carried out in triplicate. The results are expressed as mean values and standard deviation (SD). The differences between the different extracts were analyzed using one-way analysis of variance (ANOVA) followed by Tukey's significant difference post hoc test and value $p<0.05$ was considered significant. This treatment was carried out using SPSS v. 14.0 program. Graph Pad Prism software (San Diego, CA, USA, Version 6.03) was used to calculate $\mathrm{IC}_{50}$ values.

\section{Conclusions}

The present communication serves as a thorough tentative evaluation of the phytochemical composition and enzyme inhibitory capability of Buxus papillosa aerial and stem parts. The chemical composition as established by HPLC-PDA analysis has resulted in the quantification of important phenolic compounds like syringic acid, 3-OH benzoic acid, $p$-hydroxybenzoic acid, 3-OH-4-MeO benzaldehyde and naringin among others. Similarly, some of the other phytochemical derivatives belonging to flavonoid, terpenoid, alkaloid and glucoside groups were also tentatively identified by UHPLC-MS analysis. In case of enzyme assays, a moderate inhibitory activity was observed which can be corelated to the phytochemical composition. Overall, this plant species could be further explored as a potential origin for designing of new natural-product derived drug leads.

Supplementary Materials: The following are available online at http://www.mdpi.com/2227-9717/8/7/757/s1, Figure S1: HPLC-PDA chromatograms of phenolics quantified in B. papillosa aerial-MeOH extract; Figure S2: HPLC-PDA chromatograms of phenolics quantified in B. papillosa aerial-DCM extract; Figure S3: HPLC-PDA chromatograms of phenolics quantified in B. papillosa stem-MeOH extract; Figure S4: HPLC-PDA chromatograms of phenolics quantified in B. papillosa stem-DCM extract; Figure S5: HPLC-PDA chromatograms of phenolics quantified in B. papillosa stem-hexane extract.

Author Contributions: Conceptualization, M.L. and N.A. and T.T.H.; methodology, H.S., G.Z. and M.L.; formal analysis, H.S., G.Z., A.T. and M.L.; writing—original draft preparation, H.S. and S.A.Z.A.; writing-review and editing, N.A. and R.N. All authors have read and agreed to the published version of the manuscript.

Funding: The current research work has received no funding. 
Acknowledgments: Hammad Saleem acknowledges the Monash University Malaysia (School of Pharmacy) for providing Graduate Research Scholarship for doctoral studies.

Conflicts of Interest: The authors declare to have no conflict of interest.

\section{References}

1. Shendge, P.N.; Belemkar, S. Therapeutic potential of Luffa acutangula: A Review on Its traditional uses, phytochemistry, pharmacology and toxicological aspects. Front. Pharmacol. 2018, 9, 1177. [CrossRef] [PubMed]

2. Cheng, J.-X.; Zhang, B.-D.; Zhu, W.-F.; Zhang, C.-F.; Qin, Y.-M.; Abe, M.; Akihisa, T.; Liu, W.-Y.; Feng, F.; Zhang, J. Traditional uses, phytochemistry, and pharmacology of Ficus hispida Lf: A review. J. Ethnopharmacol. 2019, 248, 112204. [CrossRef] [PubMed]

3. Geethangili, M.; Ding, S.-T. A review of the phytochemistry and pharmacology of Phyllanthus urinaria L. Front. Pharmacol. 2018, 9, 1109. [CrossRef] [PubMed]

4. Huang, W.-Y.; Cai, Y.-Z.; Zhang, Y. Natural phenolic compounds from medicinal herbs and dietary plants: Potential use for cancer prevention. Nutr. Cancer 2009, 62, 1-20. [CrossRef] [PubMed]

5. Silva, N.; Fernandes Júnior, A. Biological properties of medicinal plants: A review of their antimicrobial activity. J. Venom. Anim. Toxins Incl. Trop. Dis. 2010, 16, 402-413. [CrossRef]

6. Lin, D.; Xiao, M.; Zhao, J.; Li, Z.; Xing, B.; Li, X.; Kong, M.; Li, L.; Zhang, Q.; Liu, Y. An overview of plant phenolic compounds and their importance in human nutrition and management of type 2 diabetes. Molecules 2016, 21, 1374. [CrossRef] [PubMed]

7. Bouriche, H.; Moussaoui, S.; Meziti, H.; Senator, A. Anti-inflammatory activity of methanolic extract of Santolina chamaecyparissus. In Proceedings of the International Symposium on Medicinal Plants and Natural Products 1098, Montreal, QC, Canada, 17-19 June 2013; pp. 23-30.

8. Balunas, M.J.; Kinghorn, A.D. Drug discovery from medicinal plants. Life Sci. 2005, 78, 431-441. [CrossRef] [PubMed]

9. Hamilton, A.C. Medicinal plants, conservation and livelihoods. Biodivers. Conserv. 2004, 13, 1477-1517. [CrossRef]

10. Zengin, G.; Uysal, A.; Aktumsek, A.; Mocan, A.; Mollica, A.; Locatelli, M.; Custodio, L.; Neng, N.R.; Nogueira, J.M.; Aumeeruddy-Elalfi, Z. Euphorbia denticulata Lam.: A promising source of phyto-pharmaceuticals for the development of novel functional formulations. Biomed. Pharmacother. 2017, 87, 27-36. [CrossRef] [PubMed]

11. Zengin, G.; Sarikurkcu, C.; Aktumsek, A.; Ceylan, R.; Ceylan, O. A comprehensive study on phytochemical characterization of Haplophyllum myrtifolium Boiss. endemic to Turkey and its inhibitory potential against key enzymes involved in Alzheimer, skin diseases and type II diabetes. Ind. Crop. Prod. 2014, 53, 244-251. [CrossRef]

12. Mocan, A.; Vlase, L.; Arsene, A.L.; Vodnar, D.; Bischin, C.; Silaghi-Dumitrescu, R.; Crișan, G. HPLC/MS analysis of caffeic and chlorogenic acids from three Romanian Veronica species and their antioxidant and antimicrobial proprieties. Farmacia 2015, 63, 890-896.

13. Llorent-Martínez, E.; Ortega-Barrales, P.; Zengin, G.; Uysal, S.; Ceylan, R.; Guler, G.; Mocan, A.; Aktumsek, A. Lathyrus aureus and Lathyrus pratensis: Characterization of phytochemical profiles by liquid chromatography-mass spectrometry, and evaluation of their enzyme inhibitory and antioxidant activities. RSC Adv. 2016, 6, 88996-89006. [CrossRef]

14. Khan, A.-U.; Ali, S.; Gilani, A.-H.; Ahmed, M.; Choudhary, M.I. Antispasmodic, bronchodilator, vasorelaxant and cardiosuppressant effects of Buxus papillosa. BMC Complementary Altern. Med. 2017, 17, 54. [CrossRef] [PubMed]

15. Loru, F.; Duval, D.; Aumelas, A.; Akeb, F.; Guédon, D.; Guedj, R. Four steroidal alkaloids from the leaves of Buxus sempervirens. Phytochemistry 2000, 54, 951-957. [CrossRef]

16. Yan, Y.X.; Chen, J.C.; Sun, Y.; Wang, Y.Y.; Su, J.; Li, Y.; Qiu, M.H. Triterpenoid alkaloids from Buxus microphylla. Chem. Biodivers. 2010, 7, 1822-1827. [CrossRef]

17. Yan, Y.-X.; Hu, X.-D.; Chen, J.-C.; Sun, Y.; Zhang, X.-M.; Qing, C.; Qiu, M.-H. Cytotoxic triterpenoid alkaloids from Buxus microphylla. J. Nat. Prod. 2009, 72, 308-311. [CrossRef]

18. Choudhary, M.I.; Shahnaz, S.; Parveen, S.; Khalid, A.; Majeed Ayatollahi, S.A.; Atta, U.-R.; Parvez, M. New Triterpenoid alkaloid cholinesterase inhibitors from Buxus h yrcana. J. Nat. Prod. 2003, 66, 739-742. [CrossRef]

19. Atta-ur-Rahman, M.; Choudhary, S.; Naz, A.; Ata, B. Sener and S. Turkoz. J. Nat. Prod. 1997, 60, 770. [CrossRef] 
20. Matochko, W.L.; James, A.; Lam, C.W.; Kozera, D.J.; Ata, A.; Gengan, R.M. Triterpenoidal alkaloids from Buxus natalensis and their acetylcholinesterase inhibitory activity. J. Nat. Prod. 2010, 73, 1858-1862. [CrossRef]

21. Ata, A.; Iverson, C.D.; Kalhari, K.S.; Akhter, S.; Betteridge, J.; Meshkatalsadat, M.H.; Orhan, I.; Sener, B. Triterpenoidal alkaloids from Buxus hyrcana and their enzyme inhibitory, anti-fungal and anti-leishmanial activities. Phytochemistry 2010, 71, 1780-1786. [CrossRef]

22. Cordell, G.A. Introduction to Alkaloids: A Biogenetic Approach; Wiley New York: Hoboken, NJ, USA, 1981.

23. Asif, E.; Ali, S.S.; Nasir, H.; Jamal, S.A.; Ata, A.; Farooq, A.; Choudhary, M.I.; Sener, B.; Turkoz, S. New steroidal alkaloids from the roots of Buxus papillosa. J. Nat. Prod. 1992, 55, 1063-1066.

24. Saleem, H.; Htar, T.T.; Naidu, R.; Ahmad, I.; Zengin, G.; Ahmad, M.; Ahemad, N. Investigations into the therapeutic effects of aerial and stem parts of Buxus papillosa CK Schneid: In vitro chemical, biological and toxicological perspectives. J. Pharm. Biomed. Anal. 2019, 166, 128-138. [CrossRef] [PubMed]

25. Mocan, A.; Zengin, G.; Mollica, A.; Uysal, A.; Gunes, E.; Crişan, G.; Aktumsek, A. Biological effects and chemical characterization of Iris schachtii Markgr. extracts: A new source of bioactive constituents. Food Chem. Toxicol. 2018, 112, 448-457. [CrossRef] [PubMed]

26. Yerlikaya, S.; Zengin, G.; Mollica, A.; Baloglu, M.C.; Celik Altunoglu, Y.; Aktumsek, A. A multidirectional perspective for novel functional products: In vitro pharmacological activities and in silico studies on Ononis natrix subsp. hispanica. Front. Pharmacol. 2017, 8, 600. [CrossRef] [PubMed]

27. Ozer, M.S.; Sarikurkcu, C.; Tepe, B. Phenolic composition, antioxidant and enzyme inhibitory activities of ethanol and water extracts of Chenopodium botrys. RSC Adv. 2016, 6, 64986-64992. [CrossRef]

28. Melucci, D.; Locatelli, M.; Locatelli, C.; Zappi, A.; De Laurentiis, F.; Carradori, S.; Campestre, C.; Leporini, L.; Zengin, G.; Picot, C. A comparative assessment of biological effects and chemical profile of Italian Asphodeline lutea extracts. Molecules 2018, 23, 461. [CrossRef]

29. Mocan, A.; Zengin, G.; Simirgiotis, M.; Schafberg, M.; Mollica, A.; Vodnar, D.C.; Crişan, G.; Rohn, S. Functional constituents of wild and cultivated Goji (L. barbarum L.) leaves: Phytochemical characterization, biological profile, and computational studies. J. Enzym. Inhib. Med. Chem. 2017, 32, 153-168. [CrossRef]

30. Picot, M.C.N.; Mahomoodally, M.F. Effects of Aphloia theiformis on key enzymes related to diabetes mellitus. Pharm. Biol. 2017, 55, 864-872. [CrossRef]

31. Sari, A.C.; Elya, B. Antioxidant activity and lipoxygenase enzyme inhibition assay with total flavonoid assay of Garcinia porrecta Laness. stem bark extracts. Pharmacogn. J. 2017, 9, 257-266. [CrossRef]

32. Zengin, G.; Cvetanović, A.; Gašić, U.; Stupar, A.; Bulut, G.; Senkardes, I.; Dogan, A.; Seebaluck-Sandoram, R.; Rengasamy, K.R.; Sinan, K.I. Chemical composition and bio-functional perspectives of Erica arborea L. extracts obtained by different extraction techniques: Innovative insights. Ind. Crop. Prod. 2019, 142, 111843. [CrossRef]

33. Locatelli, M.; Zengin, G.; Uysal, A.; Carradori, S.; De Luca, E.; Bellagamba, G.; Aktumsek, A.; Lazarova, I. Multicomponent pattern and biological activities of seven Asphodeline taxa: Potential sources of natural-functional ingredients for bioactive formulations. J. Enzym. Inhib. Med. Chem. 2017, 32, 60-67. [CrossRef] [PubMed]

34. Di Sotto, A.; Di Giacomo, S.; Amatore, D.; Locatelli, M.; Vitalone, A.; Toniolo, C.; Rotino, G.; Lo Scalzo, R.; Palamara, A.; Marcocci, M. A polyphenol rich extract from Solanum melongena L. DR2 peel exhibits antioxidant properties and anti-herpes simplex virus type 1 activity in vitro. Molecules 2018, 23, 2066. [CrossRef] [PubMed]

35. Saleem, H.; Htar, T.T.; Naidu, R.; Nawawi, N.S.; Ahmad, I.; Ashraf, M.; Ahemad, N. Biological, chemical and toxicological perspectives on aerial and roots of Filago germanica (L.) huds: Functional approaches for novel phyto-pharmaceuticals. Food Chem. Toxicol. 2019, 123, 363-373. [CrossRef] [PubMed]

36. Savran, A.; Zengin, G.; Aktumsek, A.; Mocan, A.; Glamoćlija, J.; Ćirić, A.; Soković, M. Phenolic compounds and biological effects of edible Rumex scutatus and Pseudosempervivum sempervivum: Potential sources of natural agents with health benefits. Food Funct. 2016, 7, 3252-3262. [CrossRef] [PubMed]

37. Baylac, S.; Racine, P. Inhibition of 5-lipoxygenase by essential oils and other natural fragrant extracts. Int. J. Aromather. 2003, 13, 138-142. [CrossRef]

(C) 2020 by the authors. Licensee MDPI, Basel, Switzerland. This article is an open access article distributed under the terms and conditions of the Creative Commons Attribution (CC BY) license (http://creativecommons.org/licenses/by/4.0/). 